\title{
Perceived Benefits of Grammar Bubbles, Compare and Falling Clouds among Grade Four Pupils
}

\author{
Aileene T. Untao \\ Mindanao State University- Integrated Laboratory School, \\ Marawi City, Mindanao, Philippines \\ Sittie Zinab M. Abaton-Abantas \\ Mindanao State University-Integrated Laboratory School, \\ Marawi City, Mindanao, Philippines
}

\begin{abstract}
The study intended to find out and describe the perceived benefits of three selected computer games using the software application from the website www.gamestolearnenglish.com. One hundred sixty-seven pupils from all the five sections were the respondents. It used a descriptive research design combining quantitative and qualitative methodology to determine the confidence level of the respondents about computer use, comfort, and enjoyment level experienced in the course of playing the games, as well as the perceived benefits gained from engaging in the computer games. Respondents answered an adapted from Nathan T. Carrthat deals with the benefits and comfort computer games provide to thepupils. They also responded to some openended questions to gather further data. The results were positive and encouraging. Majority of the respondents claim adequate exposure to computer use and reported experiencing increased motivationand interest, and a high level of enjoyment and comfort in the course of playingthe computer games.There is awarrant for the conclusion that computer games make promising learning tools and should form part of language teachers' repertoire of teaching techniques or strategies. Students are likely to wonder at the non-inclusion of new mechanisms like computers in their classroom activities or lessons. Teachers' competence in the use of computers is imperative so that they could explore, choose, and download lessons for their pupils. Although educational computer games like the ones used in this study are time-consuming, teachers must select a particular level or topic in the games that would interest the pupilsappropriate on their age and grade level.
\end{abstract}

Keywords: study habits, learning styles, study skill program, multimedia, multimedia exposure.

\section{Introduction}

Language is a dynamic living thing andis compared to human beings. It gets born, grows or develops and changes. It matures or ages, and may even decay and die like Latin and Sanskrit. Language is a natural activity. Through it, man can survive and thrive in his environment. Human language is the most unique, elaborate, or developed among all known forms of communication or sign systems. Language is part of the human genetic code; all humans are programmed to acquire or learn a language as enunciated by Chomsky in (1975) his formulations 
about the language acquisition device (LAD) and Bickerton's (1985) biological timetable for language acquisition or learning. Semantic and syntactic components of language follow a natural process, the physical environment of a child. Learning a language is an essential human activity or process, and this process has changed over time. Technological advances have vastly influenced the way language is learned and taught.

Technology in the 21st century is now widely accessible and available for school applications, for use in a language classroom. These technologies offer opportunities for teachers to teach the language diversely and more creatively to highly motivate each learner in learning the language. However, success in using electronic devices does not come automatically, nor guarantee "best practice" (Daniels and Bizar, 2005). At present, computer technology in the environment plays a significant role in developing and cultivating the language. Students come to school, bringing the rich knowledge of their first language, including the vast experience of technology they learn from their surroundings.

Tapscott (1999) said that "Students need better tools, better access, and better services - more freedom to explore, not less." Hence, if students will be given the better tools suited to their needs, successful learning can be better achieved and they may be the source of how to make their schools relevant, and useful places to learn. These tools can lend authenticity to the classroom, helping a student to understand and connect the language classrooms and the outside world.

According to Eaton (2010), the world is changing at a rapid pace. How students learn is changing. How teachers teach and assess learning is also changing. There are numerous ways that teachers can use technology in a supporting or lead role in the classroom. Best Practice teachers use the Web in school assignments, have their classroom and, or personal Web sites, are in touch with students, families, and colleagues by e-mail. They can support their students' inquiry and authoring in a wide range of media. Some private and public schools use interactive Smart Boards in place of traditional chalk or whiteboards in their classrooms. These flat-screen monitors are networked with the teacher's classroom computer and the school's internet connection. Interactive lessons in Math, spelling, Science and other subjects can be put on screen for students to participate. The boards use touch screen technology, and in some cases, kids has handheld remote "clickers" that act as controllers for answering questions presented on the screen(http://www.wisegeek.com/how-canteachers-use-technology-in-the-classroom.htm).

Albirini (2006)aimed to examine theeffectiveness of Web-based instruction in the writing of freshman EFL students, found that the use of Web-based lessons as asupplement to traditional in-class writing instruction was significantly moreeffective than teaching which depended on the textbook alone. The experimentalgroup of students received online instruction in which they posted their ownthreads, short paragraphs, stories and poems on a discussion board. They alsolocated information from the Internet, as well as wrote paragraphs and checkedtheir own spelling using Microsoft Word.

Another study by Ybarra \& Green (2016) determined whether or not theuse of computers facilitates the vocabulary development of beginning Englishlanguage learners. The study was conducted in Seoul, South Korea. The fifthgrade students learning English were assigned to three different groups. Thetypes of studies done by the three groups were: definitions, picture, and context. The group studying definitions was given the English word with the definitionwritten in Korean. This group relied mainly on rote memorization. The groupstudying pictures were given the definition as well as a picture. The third groupwas given a situational context employing the English word first, and then, wasgiven the definition and picture. Initially, 
the picture and definition groups didmuch better than the context group. However, after a few sessions, the contextgroup's scores surpassed those of the other two groups. There was also a testgiven at the end of the treatment sessions to test for retention. For this test, thecontext group scored significantly higher than the other two groups. Ybarra \& Green (2016) concluded, "The Context group subjects needed a period of timeto get used to their instructional treatment before they could take advantage ofthis more engaging type of instructional approach". In the end, the contextualapproach proved to be much more effective in promoting long-term recall ofvocabulary. This learning process was made possible and more effective by theuse of computers (http://iteslj.org/Articles/Ybarra-Technology.html).

In Taiwan, the study of Yang (2017) explores the perceptionsof a class of senior high school students regarding language learning in atechnology environment. The subjects were 4410 thgrade male students andtheir teacher who together joined technology-enhanced language learning (TELL)project in Taiwan known as "Advanced Joint English Teaching" (AJET). Thestudents participated in six Internet-based teaching activities: group e-mailing, aWeb-based course, an e-mail writing program, English homepage design, videoconferencingand chat room discussion. The study found that the AJET projectprovided the students with an opportunity to experience new technologies;learners experienced the pleasure of learning and thus increased their learningpossibilities. The students liked and approved of learning English using theInternet, but had differing opinions about its benefits. The study demonstratedthat learners bring different perspectives to TELL, and that learners who arepassively oriented towards Internet English learning require careful guidance inemploying pedagogical applications to this approach. Making students awarethat learning English through multimedia technology demands new learningstrategies and self-directed learning is a crucial first step. Some pedagogicalsuggestions are provided for effectively using computer networking in secondandforeign language classrooms.

According to BEAM (Basic Education Assistance for Mindanao), their e-learning courses for Mindanao teachers, MiSpace, is an innovation in language teaching. It is created to develop flexible delivery materials that enhance the skills of educators in Mindanao via an efficient and economical computer-based technology and the internet. BEAM supported the program because it saw that using computer-based learning materials would be both economical and flexible and would enhance the knowledge, skills, and capacity of education managers, teachers, and teacher educators (BEAM Newsletter, Vol. 4, 2005).

A classroom which has $30-40$ population or even more is difficult to handle with only the teacher talking. There is now widespread recognition of diversity as a fact: students are distinctive and different in a variety of ways. With the diverse learning styles and abilities of the students, learning and retention are not assured. The human teacher could not give all the reinforcement needed since the labor required is beyond human capacity. This achievement gap problem is not new in the MSU-IntegratedLaboratory School despite the fact that the children are now exposed to differenttechnology in a widespread scale at homes and in commercial establishments.Depressed performance is borne out by the school ${ }^{\text {ee }} \mathrm{s}$ overall outcome in entranceexaminations and the National Achievement Test (NAT), and worse, dropoutrates, which continue to be a problem. It may be difficult to pinpoint the exactcause of this problem as a host of factors may have to be taken into account.However, the problem is not that hopeless and may be remedied or minimized insome ways. This study then was undertaken to determine the perceived benefits ofselected computer games among MSU-ILS Grade Four pupils.

The researcher formulated the schematic diagram of the flow of the study which is shown below. The first part of this study centers on the use of computer technology in learning the language. 
The second part reveals and reports the benefits of the three selected computer games, both positive and negative effects. The third is concerned with the perceived enhanced skills of the pupils after exposure to computer games.

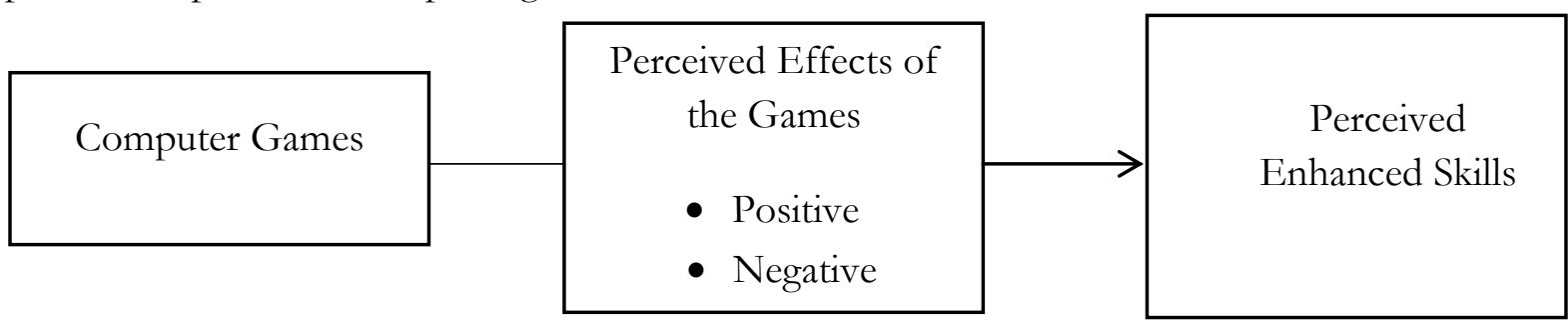

Figure 1: Schematic Diagram of the Flow of the Study

This study aimed to determine the benefits derived from trying out three selected computer games. Said benefits are ascertained by the perceived enhanced skills of the pupils after engagement in the computer games. The games were: Grammar Bubbles, Compare, and Falling Clouds. Specifically, it sought to answer the following questions: 1. What is the respondents' perceived confidence in using a computer? 2. What are the perceived comforts, enjoyment, and benefits the pupils gained from playing computer games? 3. What are the positive and negative effects of the computer games as perceived by the Grade Four pupils? 4. What are the perceived skills enhanced by the pupils in playing the three games?

\section{Literature Review}

\section{Technology and Education: Computer as Learning Tools}

There is no controversial and interesting issue that has engaged more thefield of education than what the best method, approach and tools in teaching are. The quest for the "best" method or practices has become the quest for the HolyGrail in language pedagogy. English language teachers have been involved inthe search for what method to use in the classroom to keep the learners on track.Thus, technology - computers, CD-Roms, audio and video resources, and DVDs- entered the scene, suggesting more options or possibilities for facilitating andimproving instruction and learning. Millions of books, newspaper, and even topicsin seminars and researches have been discussing the advantages of adaptingtechnology in the classroom and trying to address the problem.

Technology has been an integral part of the curriculum in severalindustrialized countries like America, Europe and around the Pacific Rim. Overthe past years, education practitioners and scholars have been includingtechnology in improving methods and techniques in the classroom instruction. Inhis article, Finn takes into account many types of programs and the whole arrayof audio-visual equipment. Moreover, using multimedia instructional techniqueswas carried on in his experimentation; it involved the combination of knowledgeof education, psychology and communication One of such technology is amachine known as the computer.

According to Bush (1998), a computer is a machine that accepts datafrom an input device, performs arithmetic and logical operations in accordancewith an internally stored program, and transfers the processed results to anoutput device. It is a machine that performs specific tasks according to specificinstruction.

Former Department of Education Secretary Lapus saw the immense promise oftechnology in education: "Technology plays a major role in creating this new andimproved model of teaching 
and learning." Through technology, education canhappen anytime and anywhere. More than just cursory knowledge or perfunctoryinterest is imperative. Third millennium or 21 st century denizens should be ableto navigate through these technologies, or fall behind in the march of progress foras generally acknowledged, technology is a significant part of nearly everyone'slife (Ban, 2008). The incontrovertible fact is, technology permeates nearlyevery facet of modern life and holds the key to solving many of humanity's mostpressing current and future challenges. Individuals should have a clearunderstanding of how automated systems are normally conceptualized,designed, procured, developed, installed and most importantly, used to maximumbenefit.

\section{Computer Games and Applications}

Psychologists believe that the basis of most children's play, starting with asimple infant amusement such as peekaboo, is imitation of adult life, particularlythat of parents or other significant figures. Play is thus a learning process and ameans of adapting to, or coping with, life situations (Microsoft Encarta, 2009). The website, Games to learn English(www.gamestolearnenglish.com), isa website created by Owen Dwyer last 2014. It lets the children have fun playing computerwhile learning. Different games are available for different students' needs. Thegame's focus is to learn the English language in a multimedia setting, specificallygrammar, vocabulary, and comprehension skills, and the like.

Most of Cheng's (2018) written and published works on educationalgames are based on analyzing a game's potential for education. She cited a simple memory game with cardsused for learning new words. Each card contains a new word to learn. A studenthas to memorize the word as well as its location. It was developed with theHyperCard environment (Macintosh), using HyperTalk as scripting language.

Cheng (2018) gives the explanationabout all the learning principles involved in playing software games. Popularcommercial non-educational games are learning tools and create a "cycle ofexpertise," a principle that suggests that computer games are also powerfullearning tools. $\mathrm{He}$ states that an educational game should promote off-linelearning. He cited two popular games, Age of Empires and Age of Mythology,that promote historical and mythological topics. Moteram (2017) also agreed thatstudents need proper motivation to acquire new concepts. This motivation is present in computer games.

\section{Integrating Technology for Added Value to Teaching and Learning}

Technology integration in teaching and learning has been identified as oneof the effective teaching practices (Grant, et al., 2013). The termtechnology integration is defined as "the pervasive and productive use ofeducation technologies for purposes of curriculum-based teaching and learning."Obviously, the definition does not endorse the use of technology for technology'ssake. It does, however, support the notion that the use of technology is likenedto choosing appropriate instructional resources to support learning in theclassroom. Put more concisely and succinctly, technology is used to support thecurriculum.

One innovative way to think about the integration of technology has emerged through the development of a framework called TechnologicalPedagogical Content Knowledge (TPCK). Essentially, TPCK posits that teachersneed to know the interrelationships of various types of teaching and learningknowledge for successful technology integration.

Pedagogical content knowledge (PCK) is knowledge about how toeffectively teach a particular discipline. Both expert knowledgeor excellent knowledge about the content of a discipline and pedagogical contentknowledge are required for becoming or being an expert teacher. An 
expertteacher knows the structure of his discipline and this knowledge gives them theability to create cognitive road maps that give the assignments he/she gives tostudents, the assessments he/she uses to evaluate students' progress, and thetypes of questions and answers he/she generates in class (Santrock, 2004). Being an expert teacher in a particulardiscipline also involves being aware of which aspects of discipline are especiallydifficult or easy for students to learn.

\section{Method}

\section{Participants}

The respondents of the study were Grade Four pupils of MSU-ILS, School Year 2014-2015. The researcher chose this population -- grade four pupils because children are fond of playing games, especially computer games.Moreover, based on an initial survey made by the researcher herself, most of therespondents had a computer (PC), laptop, tablet, and a cellphone, eitherpersonal or owned by their family members. This age also is a transition period wherein theybecome more mature and more inquisitive about their surroundings. In Erikson'sLife-Span Development Theory, this is the fifth psychosocial stage whenchildren's initiative brings them into contact with a wealth of new experiences. Atno time, according to Erikson (Santrock, 2004), are children moreenthusiastic about learning than at the end of early childhood, when theirimagination is expansive. As they prepare to move into the elementary years andearly adolescence, they direct their energy toward discovering new knowledgeand mastering this and intellectual skills acquired.

A total of 175 pupils from different sections namely, A, B, C, D, and E,were the respondents to participate in the activity, that is to play computergames in the school's Laboratory Room. However, out of this number, only onehundred sixty-seven (167) questionnaires were retrieved. Thus, this numberfinally composed the sample of the study, with 71 males and 96 females.

\section{Design}

The researcher adopted the descriptive, qualitative, and quantitativedesign in this inquiry.These research designs will answer the problem ongathering the data during class activities involving the use of computer games for the observation and critical examination of the comfort and enjoyment the respondents experienced while engaged in the games, as well as the benefits they acquired from these games. The study'sintent entailed the gathering of both quantitative and qualitative data.

\section{Materials}

The researchers used a questionnaire to determine the pupils' exposure to and confidence inusing a computer.The questionnaire adapted from Carr et al. (2014) has four parts. Part 1 shows the Student's Confidence and Exposure to Computer with five questions and four scales: Very Confident (4), Confident Enough (3), Less Confident (2), and Not Confident (1). Part 2 determines the Benefits from the Computer Games has fifteen questions and four scales as well: Most Beneficial (4), Beneficial (3), Less Beneficial (2), and Not Beneficial (1). Part 3 identifies the Comfort and Enjoyment experienced in playing Grammar Bubbles, Compare, and Falling Clouds with five questions and four scales: A lot (4), A little (3), Fair (2), and Not at all (1). The last part is the interview guide questions that ask on the positive and adverse effects of computer games and what are the skills that were enhanced by the computer games.

The researchers chose the website Games to Learn Englishto download the three software applications because these childrenare known to enjoy playing computer games. This particular website isintended or designed for children learning English as a second language. The three computer games used in this study were FallingClouds, Grammar Bubbles, and Compare. 


\section{Procedure}

The researcher drew up a time plan for the conduct of the research tomaximize the limited time available and avoid wastage.An approved letter from the MSU-ILS Elementary Principal seeking permission toconduct the study and stating the purpose of the undertaking. The letter includedsuch essential information as the participants involved in thestudy. All grade four pupils of the school are therespondents of the study. The researcherused the questionnaire adapted from Carr et al. (2014) that deals with the benefits and comfort computer games provide to thepupils. She also raised some open-ended questions to obtain further desired data.

There was no individual interview. Instead, the respondents were instructed towrite words and sentences they remembered from their experience of the gamesto record their impressions, thoughts, and feelings. The researcher herselfpassed out the questionnaires to all the respondents to make sure that whateverquestions raised would be immediately attended. Distribution was done bysection as it was difficult to gather in one setting, and at once, all target 175 Grade 4 pupils. There were only 167 retreived questionnaires bacause of irregular attendance of few due to sickness and unexpected circumstances.

\begin{tabular}{|l|l|l|l|}
\hline & Male & Female & Total \\
\hline Actual Number of Grade Four Pupils & 74 & 101 & 175 \\
\hline Number of Retreived Questionnaires & 71 & 96 & 167 \\
\hline
\end{tabular}

\section{Study Results}

Table 1: Respondents' Confidence Level in Using the Computer

\begin{tabular}{|l|l|l|l|l|l|}
\hline Indicators & $\mathbf{N}$ & Sum & Mean & $\begin{array}{l}\text { Standard } \\
\text { Deviation }\end{array}$ & Description \\
\hline $\begin{array}{l}\text { Play computer games (Texttwist, Hangaroo, } \\
\text { Bookworm, and others) }\end{array}$ & 167 & 555 & 3.32 & 1.008 & $\begin{array}{l}\text { Very } \\
\text { Confident }\end{array}$ \\
\hline Using a computer inschool activities & 167 & 551 & 3.30 & 0.948 & $\begin{array}{l}\text { Very } \\
\text { Confident }\end{array}$ \\
\hline $\begin{array}{l}\text { Searching the internet forassignments, } \\
\text { projects, and others }\end{array}$ & 167 & 513 & 3.07 & 1.138 & Confident \\
\hline $\begin{array}{l}\text { Using Microsoft word inmaking assignments, } \\
\text { projects, and others }\end{array}$ & 167 & 479 & 2.87 & 1.106 & Confident \\
\hline $\begin{array}{l}\text { Visiting Facebook, Twitter,Instagram account } \\
\text { to communicate and make friends }\end{array}$ & 167 & 449 & 2.69 & 1.217 & Confident \\
\hline Grand Mean & & $\mathbf{3 . 0 5 0}$ & & Confident \\
\hline
\end{tabular}

Scaling: $\quad 1.00-1.75=$ Not Confident

$1.76-2.51=$ Less Confident

$2.52-3.27=$ Confident

$3.28-4.00=$ Very Confident

Table 2: Respondents' Perceived Comfort and Enjoyment Level

\begin{tabular}{|l|l|l|l|l|l|}
\hline Indicators & $\mathbf{N}$ & $\begin{array}{l}\text { Su } \\
\mathbf{m}\end{array}$ & Mean & $\begin{array}{l}\text { Standard } \\
\text { Deviation }\end{array}$ & Description \\
\hline Enjoy using the Games to Learn English & 167 & 620 & 3.71 & 0.641 & A lot \\
\hline The game increases interest in learning English & 167 & 585 & 3.50 & 0.835 & A lot \\
\hline Degree of comfort felt using games to learn English & 167 & 573 & 3.44 & 0.681 & A lot \\
\hline $\begin{array}{l}\text { Experience in using the games to learn English as a } \\
\text { student }\end{array}$ & 167 & 563 & 3.37 & 0.825 & A lot \\
\hline
\end{tabular}




\begin{tabular}{|l|l|l|l|l|l|}
\hline $\begin{array}{l}\text { Level of difficulty encountered upon learning a new } \\
\text { word in the game }\end{array}$ & 167 & 385 & 2.31 & 1.118 & A little \\
\hline Grand Mean $1.00-1.75=$ Not at all \\
Scaling: $1.76-2.51=$ A little \\
2.52- 3.27 = Fair \\
$3.28-4.00=$ A lot
\end{tabular}

Table 3: Benefits Perceived on the Games asPerceived by the Respondents

\begin{tabular}{|l|l|l|l|l|l|}
\hline Indicators & $\mathbf{N}$ & $\begin{array}{l}\text { Su } \\
\mathbf{m}\end{array}$ & $\mathbf{M e a n}$ & $\begin{array}{l}\text { Standard } \\
\text { Deviation }\end{array}$ & Description \\
\hline Developing students motivation tolearn a new idea & 167 & 593 & 3.55 & 0.717 & $\begin{array}{l}\text { Most } \\
\text { Beneficial }\end{array}$ \\
\hline Enhance spelling ability while in thegame & 167 & 578 & 3.46 & 0.827 & $\begin{array}{l}\text { Most } \\
\text { Beneficial }\end{array}$ \\
\hline Learning the procedure in doing the activity quickly & 167 & 572 & 3.43 & 0.846 & $\begin{array}{l}\text { Most } \\
\text { Beneficial }\end{array}$ \\
\hline Learning vocabulary from the game & 167 & 570 & 3.41 & 0.823 & $\begin{array}{l}\text { Most } \\
\text { Beneficial }\end{array}$ \\
\hline Construct simple sentences & 167 & 567 & 3.40 & 0.885 & $\begin{array}{l}\text { Most } \\
\text { Beneficial }\end{array}$ \\
\hline $\begin{array}{l}\text { Develop the sense of willingness toaccomplish the } \\
\text { activity }\end{array}$ & 167 & 560 & 3.35 & 0.919 & $\begin{array}{l}\text { Most } \\
\text { Beneficial }\end{array}$ \\
\hline It relates the past to new learningexperiences & 167 & 559 & 3.35 & 0.806 & $\begin{array}{l}\text { Most } \\
\text { Beneficial }\end{array}$ \\
\hline Practicing sentence order & 167 & 558 & 3.34 & 0.834 & $\begin{array}{l}\text { Most } \\
\text { Beneficial }\end{array}$ \\
\hline Encourage active participation & 167 & 548 & 3.28 & 0.944 & $\begin{array}{l}\text { Most } \\
\text { Beneficial }\end{array}$ \\
\hline Develop higher-order thinking skills & 167 & 538 & 3.22 & 0.846 & Beneficial \\
\hline It discourages boredom in doing the activity & 167 & 537 & 3.22 & 0.952 & Beneficial \\
\hline Enhances grammar skills & 167 & 528 & 3.16 & 0.984 & Beneficial \\
\hline Develop visual skills & 167 & 527 & 3.16 & 0.975 & Beneficial \\
\hline The activity connects with the real world & 167 & 518 & 3.10 & 1.039 & \begin{tabular}{l} 
Beneficial \\
\hline Provides immediate outcome
\end{tabular} \\
\hline Grand Mean & & 310 & 3.05 & 0.965 & Beneficial \\
\hline Scaling & & 3.299 & & $\begin{array}{l}\text { Bost } \\
\text { Beneficial }\end{array}$ \\
\hline
\end{tabular}

Scaling: $\quad 1.00-1.75=$ Not Beneficial

$1.76-2.51=$ Less Beneficial

$2.52-3.27=$ Beneficial

$3.28-4.00=$ Most Beneficial 
Table 4: Respondents' Positive Perceptions

\begin{tabular}{|l|l|l|l|l|l|}
\hline Indicators & $\mathbf{N}$ & Sum & Mean & $\begin{array}{l}\text { Standard } \\
\text { Deviation }\end{array}$ & Rank \\
\hline Enjoying & 167 & 90 & 0.54 & 0.50 & 1 \\
\hline Full of learning & 167 & 85 & 0.51 & 0.50 & 2 \\
\hline Interactive participation & 167 & 13 & 0.08 & 0.27 & 3 \\
\hline Others & 167 & 3 & 0.02 & 0.13 & 4 \\
\hline
\end{tabular}

Table 5: Respondents' Negative Perceptions

\begin{tabular}{|l|l|l|l|l|l|}
\hline Indicators & $\mathbf{N}$ & Sum & Mean & $\begin{array}{l}\text { Standard } \\
\text { Deviation }\end{array}$ & Rank \\
\hline Time-consuming & 167 & 70 & 0.419 & 0.495 & 1 \\
\hline Difficult to handle & 167 & 66 & 0.395 & 0.490 & 2 \\
\hline Discouraging & 167 & 26 & 0.156 & 0.364 & 3 \\
\hline Others & 167 & 11 & 0.066 & 0.249 & 4 \\
\hline
\end{tabular}

Table 6: Respondents' Perceived Skills Enhanced

\begin{tabular}{|l|l|l|l|l|l|}
\hline $\begin{array}{l}\text { Games to learn English } \\
\text { enhances different skills }\end{array}$ & $\mathbf{N}$ & Sum & Mean & $\begin{array}{l}\text { Standard } \\
\text { Deviation }\end{array}$ & Rank \\
\hline Grammar Skills & 167 & 100 & 0.599 & 0.492 & 1 \\
\hline Vocabulary Skills & 167 & 68 & 0.407 & 0.493 & 2 \\
\hline Comprehension Skills & 167 & 34 & 0.204 & 0.404 & 3 \\
\hline
\end{tabular}

\section{Discussions}

Table 1 presents the perceived confidence of the pupils in using acomputer. As immediately evident from the result, the respondents expressed avery high level of confidence -- that is Very Confident -- in using a computer for school activities, with a mean of 3.30 and standard deviation of 0.948 and inplaying computer games like Text Twist, Hangaroo, Bookworm, and others, with a meanof 3.32 and standard deviation of 1.008. These two indicators rank the highest. Theyreported a slightly lower level of confidence -- Confident -- in searching the netfor assignments, projects, and others, with a mean of 3.07 and SD of 1.138; in using MSWord in making assignments, projects, and others, with a mean of 2.87, and SD of 1.106, and in visiting or opening a social media like FB, Twitter, and Instagram,with a mean of 2.69 and SD of 1.217.

The overall result indicated by the grand mean of 3.050 has the qualitativeor descriptive equivalent of Confident,thus read as positive. It lends support toexisting literature and the findings of previous studies (Cooper \& Kiger, 2009;Daniels \& Bizar, 2005; Santrock, 2004) that the technology revolution or Age ofInformation Technology has dawned and students are now technologicallyoriented and computer literate. They are growing up in a world that is far differenttechnologically from the world in which their grandparents and parents lived.Technology permeates nearly every facet of modern life. The data reveals thatmost of the respondents showed preparedness, readiness, and much confidencein using a computer. The socioeconomic background can part explain the result that most of the respondentsbring with them to school. They are mostly children or dependents of Universityemployees and other government personnel. In other words, their families' socioeconomic status allows the inference that these pupil respondents haveexposure to computer use. Their parents or elder siblings can be presumed tohave computers (PCs) or laptops that they could use. 
According to Hirschbuhl and Bishop (2002), children most frequentlycited their fathers as the family member who taught them about computertechnology. It has been stressed repeatedly in numerous studies on technologyuse in education that not only "Best Practice" teachers but also parents ofstudents should be technologically literate. The pupil-respondents, however,also said that their siblings, neighbors, and other people taught them aboutcomputers. This finding implies that the respondents were already exposed tocomputers beforehand. In other words, they have a head start that their teachersshould capitalize on, or exploit.

Table 2 shows the perceived comfort and enjoyment level experiencedby the pupil respondents while playing the games. First among the list ofindicators is, the respondents enjoy using the Games to Learn English, with amean of 3.71 and a standard deviation of 0.64, which has the descriptive orqualitative equivalent of a lot. Next, the game increases their interest in learning English with a 3.50 mean and SD of 0.835. The indicator degree of comfort using Games to Learn English registered amean of 3.44 and SD of 0. 681 meaning a lot. Experience in using Games toLearn English as a student with a mean of 3.37 and SD of 0.825 also earned thedescriptive rating a lot. The indicator level of difficulty encountered upon learninga new word from the game, with a mean of 2.31 and SD of 1.118, rated a little.

On the whole, the result indicated by the grand mean of 3.266, which isinterpreted qualitatively as Fair, is positive and encouraging. Salutaryeffects, specifically enjoyment or fun, increased interest, comfort, and experiencegained, of engaging in the computer games surfaced and were all reported bythe respondents as strongly felt or perceived. In AffectiveFilter Hypothesis Tomlinson (2002) emphasized in his works that relaxed and well-confident learnerslearn faster. Research has shown, they all argue, the effects of various forms ofanxiety on learning: the less anxious the learner, the more efficiently oreffectively learning occurs and proceeds. Russian language learning researchersand Lozanov (Brown, 2000) who popularized Suggestopedia, placea premium on the relaxed or tension-free state as a condition for learning. In thisstate, super learning (hypermnesia) occurs, and there is an increase of retention.

On the other hand, some of the respondents encountered a little difficultylearning new words from the games. This difficulty was so far the only problem, ornegative result that emerged in regard to effective benefits realized from the use ofcomputer games. It can, however, implied with enough confidence that thelittle difficulty encountered by the respondents was the result of the comfort andenjoyment they experienced while playing the games. In other words, this littledifficulty was just part of the game. As an optimist or positive thinker would view it, this little difficulty could be contributory to making the games more interesting,challenging, and, most of all, enjoyable. Tomlinson (2002) haswarned against the pitfall of making the lesson/task too simple or easy forstudents. There is the possibility of this process, succeeding in diminishing thelearners or lowering their self-confidence and self-esteem. When learnersbecome aware that it is not challengingto use their brains and thattheir apparent success is only an illusion, awareness leads to reducedconfidence. Tomlinson (2002) urges teachers to build learners' confidence throughactivities which try to "push" learners slightly beyond their existing proficiency orlevel of competence by engaging them in tasks that are stimulating, which arechallenging but achievable. In other words, there should be more activities thatengage students' minds, challenging them to be more imaginative, creative, oranalytical.

Table 3 presents the benefits the pupils gained from playingcomputer games, based on their perceptions. As shown, the games wereMost Beneficial for them to develop motivation to learn a new idea, to enhance spelling ability, to learn quickly a procedure, a vocabulary,andin constructing simple sentences, to develop some sense of willingness toaccomplish an activity, in relating the past to new learning experiences, inpracticing sentence order, and to encourage 
active participation, with the meanof $3.55,3.46,3.43,3.41,3.40,3.35,3.35,3.34$, and 3.28, respectively.Furthermore, the games were also Beneficial for them to develop higherorderthinking skills, to discouarge boredom while doing an activity, to enhance theirgrammar skills, to develop their visual skills, in connecting with the real world,and to provide immediate outcome, with the mean of 3.22, 3.22, 3.16, 3.16,3.10, and 3.05, respectively.

All added up, the overall result, as indicated by the grand mean of 3.299, isMost Beneficial, thus positive and very promising.It is noticeable how the indicator concerning motivation to learn a new ideadominates. As generally recognized, motivation is a critical factor in any severe endeavor like learning and mastering a skill. Moteram (2017) has this convictionthat students need proper motivation to acquire new concepts. This motivation is present in computer games.

The most well-remembered works of Jerome Bruner deal with motivation,precisely intrinsic motivation, which he believes is the more important kind ofmotivation. It is this kind of motivation that is at work in playing games forlearning purposes.

In Bruner and another famous constructivist, Dewey, the leading exponent of experiential and discovery learning, one finds a meeting or marriage of minds.(http://simplypsychology:org/brunner, 2013). For both constructivists, learningmust be understood as a process, and not in terms of outcomes. The primary focus should be on engaging students in a processthat best enhances their learning and provides immediate feedback as games do. The constructivist teacher employs tools such as problem-solving andinquiry-based learning activities and adapts or integrated technology in herteaching, such as videos, filmstrips, movies, software applications like gamesthat create authenticity and thus increase learners' motivation to learning. Through the guidance of the teacher and the use of interactive media,students construct their knowledge and understanding actively rather than justmechanically or passively ingest knowledge from their teacher or their textbooks.

The results, particularly those having to do with motivation, learningvocabulary, willingness to accomplish the activity, encouraging activeparticipation, ease or facility in learning the procedure for doing the activity, andrelief from monotony and boredom, confirm the findings of Dirimbangan (2009).With the aid of language games, the students' learning was enhanced and mademore meaningful. Moreover, the participating learners used the target languagespontaneously in a naturalistic context. In this context, their attention wasdecentered or diverted from grammatical rules as they applied themselves to thetask and their goal. The students enjoyed the activities; they had fun.

Table 4 reveals the positive of computer games. The majority of the pupilssaid they enjoyed playing the games, with a mean of 0.54 and a standarddeviation of 0.50 , earning for it - enjoying - the 1st rank. Following as a closesecond is full of learning, with a mean of 0.51 and SD of 0.50 . The games alsohad encouraged interactive participation among themselves. This obtained amean of 0.08 and SD of 0.57 .

The overall result is positive, reflecting the respondents' total involvementin the activity. Both the affective and cognitive are engaged. -- enjoying andinteractive for the affective and learning for the cognitive. The nearly equal ratingof enjoying and full of learning suggests something important: enjoyment or fundoes not entirely dominate as to eclipse learning. As pointed out by Tomlinson (2002), learners' attention is an important input. One should be cautious that the fun element does not eclipse what linguistic feature.

As regard to interactive participation, much of the fun derived from playing games is the result of being highly interactive. Spontaneous orunconscious use of language for communication or 
interaction purposes ischaracteristic of classroom activities like educational games. The interactionist inVygotsky emphasizes the importance of educational tools to the socioculturalapproach. These are items in the culture such as computers, books, andtraditions that teach children about the expectations of the group(http://social.jrank.org/pages/142/Cognitive-Development-Vygotsky-

SocioculturalTheory.html). Software applications are educational tools. Computer applications likeEnglish language games can influence the teaching instruction in the academicinstitution. These tools are very relevant to the learners; hence, their presence intheir culture and their use of it. It is through the application of different approaches,pedagogy, and exposure to multimedia that the teachers teach language skills,and the students learn them.

Moreover, the "total involvement" that engagement in games compels ordraw from learners anchored in the Multiple Intelligences of Gardner (2014). Nearly,all or most of the senses or intelligence of players are engaged, such as visual, kinesthetic, spatial, auditory, interpersonal (when working in groups), logical, and others.The impact of Gardner's formulation, the Multiple intelligences (MI) theory, on theexploitation of multimedia for learning purposes is highly recognized. This impact has forced recognition of the fact that eachindividual has learning styles and habits of mind that exert significant influence overhow he/she learns - and further that, if properly tapped, offer a vibrant sharing oftalents, views, and voices.

The pupil respondents' comments quoted serve as convincing testimonies thatindeed, computer games encouraged learning and providedmeaningful learning experiences. Their statements are congruent with thetabulated data. Enjoyment or fun and learning are the most common answers.These two aspects are not mutually exclusive; they shouldgo together.The idea of playing and learning at the same time appeals to them. One of the respondents also referred to opportunities games afford to exercise the MultipleIntelligences. This particular answer is very typical of learners of their age. Theirstore of energies requires activities like games that engage not only their mindsbut their other "intelligence" or skills.

Furthermore, during the conduct of this study, the pupils were very excitedand showed interest and enthusiasm to participate in the activity.Most of the respondents insisted on playing the three games again. Thisexcitement expressed desire for a replayor repetition of the activity suffices as evidence ofthe impact of the games - that is stimulation or motivation -- on them. They wouldeagerly read aloud and answer simultaneously as the sentences displayedon the monitor. The games drew maximum participation from the respondents.

Table 5 depicts the adverse effects of the games. The respondents saidthat the games were timeconsuming; this obtained a mean of 0.419 and SD of0.495. The pupils experienced some problems with finishing the games becauseeach game needed enough time to complete. Some of them also encounteredsome difficulty handling the games; this registered a mean of 0.395 and SD of 0.490 . They said that the games were different from the ones in the Net cafes,which were eye-catching and had visual effects and quality. Some of themdisclosed that they were discouraged because they did not accomplish the games due to their poor background in English; this got a meanof 0.156 and SD of 0.364 . This discouragement inevitably detracted from thepositive impact of the games, but this was limited to a statistical minority basedon the relatively low mean of 0.156 .

Lastly, the other adverse effects of the computer games posted a meanscore of 0.066 and SD of 0.249. The respondents would not like to play computergames in school because their teachers are already "geniuses." Another reasonadvanced for resistance or aversion to playing computer games is, the disruption of their lessons. The latter suggests alack of appreciation of technology 
integration in learning. Some respondentsmistakenly saw the games as some activity merely tacked on, and not an integralpart of the lesson. The computer games provide support to teaching andlearning.

According to the study of Gandamra (2012), students are sensitive toaspects of the physical environment about their learning. In other words, if the school environment, that is, including their classmates and their teachers, isnot conducive and supportive, they find learning something new in school adistraction. As stressed by Frank (2005), there are conditions under whichactive learning takes place; these significantly affect the learners" experience.He urged "the intentional creation of a challenging, supportive, and relevantlearning community that allows all learners to achieve at their highest potential. Every school's goal is to develop supportive learning environments to increasestudent achievement and success in all domains: intellectual, emotional, social,spiritual, and academic.

Table 6 reveals the perceived skills enhanced in playing the threesoftware applications -Grammar Bubbles, Falling Clouds, and Compare. Out of167 respondents, the majority or 100 of them said that the games enhanced theirgrammar skills and spelling (considered under Grammar Skills); this has a meanof 0.599 . Sixty-eight of them answered that their vocabulary increased; thisregistered a mean of 0.407 . This data shows that the respondents learned new words, and they were conscious of their spelling. Only 34, comprising a small proportionof the total of 167, disclosed that the games also developed their comprehensionskills; this posted a mean of 0.204. The outcome provides positive evidence forthe use of computer games as learning tools.From the overall result can be gleaned that the computer games proveduseful and supportive of learning in certain areas, correctly spelling, andvocabulary, and to a more limited extent, comprehension.

Aside from spelling and vocabulary skills, the pupils also reportedenhancement of their word order skills, sentence construction skills, and,surprisingly, their grammar skills, like subject-verb agreement. There was one amongthem who gave a sentence with the cause-effect relationship: "I love puppiesbecause they are cute..." Besides, this statement is a complex sentence.The same respondent gave a compound sentence: "I like apples, but most of all, I like watermelons." Still, the same respondent gave a significant sentence: "I cannotspend time to play with my father again."The meaning conveyed by this statement could be this: Since this pupilwill now be playing computer games in school, his or her time playing/bondingwith the father is likely to be sacrificed.

Finally, when the researcher asked the respondents to write ten words and usethem in a sentence, the amount or percentage of retention and learning turnedout to be impressive enough, indicating that they were able to retrieve or recallmost of the words in the games and use them in sentences. Informationprocessing occurred: input became intake (underscoring provided by theresearcher. This data means there was successful absorption of the input from thecomputer games, and said input had internalized to become part of thecognitive framework or system of the learner. There was meaningful learning, to borrow an essential concept of learningpopularized by Ausubel (Brown, 2000). According to Ausubel's cognitive learning theory, learning takes place in the human organism through ameaningful process of relating new events or items to already existing cognitiveconcepts or propositions, hanging new items on existing pegs.

Hence, the computer games the respondents played did not only entertainor afford them pleasure, but also facilitated learning of spelling and vocabulary, and at the same time offered opportunities for active participation and interactiondespite their different cultural backgrounds. 


\section{Conclusion}

Based on the findings of the study, the researcher concluded that computer gamesand other forms of learner-centered, interactive, stimulating, and engaging interventionor teaching strategies can mediate, facilitate and enhance learning, thus improving outcomes. The computer games used in the inquiry demonstrate at itsbest technology integration in the education of the youth.

Computer games are not the solution to the problems ofunderachievement, retention, failure, and dropout, as these are complex andhave their deep roots in structural injustice - inequities or inequalities,impoverished foundations, deficits that can trace to family problems, and others -and therefore cannot be eradicated at one stroke or by simplistic approaches. These are huge problems that are beyond the power of individual teachers andschools to solve.

The choice of teaching strategies like computer games and other forms ofintervention is crucial and requires thoughtful planning. A framework like Technological Pedagogical Content Knowledge (TPCK) helps. In participating inengaging and challenging activities like computer games, students do not onlydevelop various skills and suchintelligence; they alsodiscover their strengths and inadequacies.

A variety or array of options is available to the language resourceful and committed teacher. It is keeping abreast of the trends to adapt and integratetechnology and use it wisely and adequately to support teaching and the curriculum. Technology pervades modern life, thus must be accepted as part of the lives ofstudents. In other words, students can immediately relate and getfully engaged. Computer games must have a place in the language teacher'srepertoire of teaching techniques or strategies, as the findings of this studysuggest.

\section{Recommendations}

Taking serious account of the findings and conclusions researcher recommends the following:

- The Grade Four English and Reading teachers need to include in their scheme of work the three computer games, namely: Falling Clouds, Compare, and Grammar Bubbles as a tool in teaching. They should not, however, limit themselves to these applications. There are more that they can explore, download, and try out with their pupils.

- Computer units and other ICT equipment like audiovisual equipment, LCDs, laptops, and others are of importance to any school; hence, school administrators should ensure the procurement of additional units to meet the the needs of the growing student population. The creation of a challenging, supportive, responsive and relevant learning environment that allows all learners to develop their full human potential - intellectual, emotional, social, academic, moral-spiritual, aesthetic, physical - is the primary responsibility of school administrators. Each department should have a Computer Room/Laboratory.

- Technology must be fully-recognized as a support to the curriculum, hence, the need to accord it the prominence it deserves in the curriculum. Websites like www.gamestolearnenglish.com must be included in the curriculum.

- Professional development activities like seminar-workshops and lecture series on teaching strategies and methods that incorporate technology tools such as some computer games should be sponsored and conducted by the unit. Teachers in the early and elementary years must realize that technophobia does not make for a "best practice" in teaching. A wide range of computer/Internet uses or applications waits to be explored. In fact, they have to catch up with their students who are active computer users. Digital technology is changing at an amazing rate. Teachers must have the ability or competence to use it themselves and communicate how to use it effectively to students. 
- Teachers themselves must model the proper, responsible, and wise use of technology. More than technological skills must be taught; relevant ethical principles or values must be instilled in students early on - e.g. the now ubiquitous "cut-and-paste" habit, plagiarism, and others.

- A similar study using some software applications with the administration of pretest and posttest may be considered by other workers in the field. Other studies should be done using some educational computers to determine and evaluate their advantages and benefits to the teachers and the students. Finally, it should be interesting to conduct studies that include variables or factors that have relevance or saliency for effective technology integration and use, for example, socioeconomic status, type of school attended (private or public), environmental factors, attitude towards technology, media exposure, and others.

\section{References}

Albirini, A. (2006). Teachers' attitudes toward information andcommunication technologies: the case of Syrian EFL teachers. Computers and Education, 47(4), 373-398.

Ban, R. (2008). Teaching English Language Learners throughTechnology. UK: Routledge.

Bishop, D., \& Hirschbuhl, J. (2002). Annual Editions: Computers in Education. Guilford, CT 06437: McGraw-Hill/Dushkin, A division of The McGraw-Hill Companies.

Brown, D. H. (2000). Principles of Language Learning and Teacbing. Third Edition. Englewood Cliffs, New Jersey: Prentice Hall, Inc.

Bush, M. (1998). Review of Technology-Enhanced Language Learning. Language Learning \& Technology, 1(2), 20-22.

Carr, N. T., Crocco, K., Eyring, J. L., \& Gallego, J. C. (2011). Perceived benefits of technology enhanced language learning in beginning language classes. The IALLT Journal, 41(1), 132.

Cheng, I., Goebel, R., Basu, A., \& Safont, L. (2018). Multimedia in Education: Adaptive Learning and Testing. World Scientific Publishing Co. Pte.Ltd.

Cooper, D., \& Kiger, N. (2009). Literacy: Helping Students Construct Meaning. Seventh Edition. Boston: Houghton Mifflin Company.

Daniels, H., \& Bizar, M. (2005). Teaching the Best Practice Way: Methods That Matter, K-12. Portland, Maine: Stenhouse Publishers.

Dirimbangan, Z. (2009). The Use of Language Games for Vocabulary Enhancement Among High School Students in MSU Community College English Courses (Unpublished Master"es Thesis), Mindanao State University, Marawi City.

Dwyer, O. (2014). Games to Learn English. Retrieved from www.gamestolearnenglish.com.

Eaton, S. E.(2010).Global Trends in Language Learning in the 21st Century. Calgary: Onate Press.

Frank, T. H. (2005). The Handbook for Developing Supportive Learning Environments. Larchmont, NY 10538: Eye on Education.

Gandamra, J. (2012). Determinants of the Learning Style Preferences of English 3 (Oral Communication) Students (Unpublished Master's Thesis), Mindanao State University, Marawi City.

Gardner, J. (2014). Oral History and Video in Theory and Practice. Oral History Review, 12(1), 105-111.

Grant, L., Jennifer, H., \& Stronge, J. (2013). Planning, Instruction, and Assessment: Effective Teaching Practices. Larchmont, NY 10528: Eye on Education.

Moteram, G. (2017). Innovations in learning technologies for English Language Teaching. British Council.

Santrock, J. W. (2004). Educational Psychology. Second Edition, Boston: McGraw-Hill Higher Education.

Tapscott, D. (1999). Educating the Net Generation. Educational Leadership. pp. 7-11.

Tomlinson, B. (2002). Materials Development in Language Teaching. Cambridge CB2 2RU, UK: Cambridge University Press.

Yang, S. (2017). Technology-enhanced language learning: A casestudy. Computers in Human Behavior Volume, 23(1), 860-879. 
Ybarra, R., \& Green, T. (2016). Using Technology to Help ESL/EFL Students Develop Language Skills. The Internet TESL Journal, 9(3).

\section{Appendix 1}

\section{Sample Questionnaire}

\section{Part I. Student's Confidence and Exposure to Computer}

Directions: Encircle four (4) if for very confident; three (3)if confident enough; two(2) if less confident, and one(1) if not confident.

\begin{tabular}{|l|l|l|l|l|l|}
\hline 1 & Using a computer in school activities & 4 & 3 & 2 & 1 \\
\hline 2 & $\begin{array}{l}\text { Using Microsoft word in making } \\
\text { assignments, projects, and others }\end{array}$ & 4 & 3 & 2 & 1 \\
\hline 3 & $\begin{array}{l}\text { Searching the internet for assignments, } \\
\text { projects, and others }\end{array}$ & 4 & 3 & 2 & 1 \\
\hline 4 & $\begin{array}{l}\text { Visiting Facebook, Twitter, Instagram } \\
\text { account to communicate and make } \\
\text { friends }\end{array}$ & 4 & 3 & 2 & 1 \\
\hline 5 & $\begin{array}{l}\text { Play computer games (Text twist, } \\
\text { Hangaroo, Bookworm, and others) }\end{array}$ & 4 & 3 & 2 & 1 \\
\hline
\end{tabular}

Legend: 4- Very confident 3-Less confident 2 - Confident 1- Not confident

\section{Part II. Benefits from the Computer Games}

Directions: Encircle four(4) if the game was most beneficial; three (3) if beneficial; two(2) if lessbeneficial, and one (1) if it is not beneficial. What are the benefits of playing computer games

(Grammar Bubbles,Compare, and Falling Clouds)in English language class?

\begin{tabular}{|l|l|l|l|l|}
\hline 1. Learning vocabulary from the game & 4 & 3 & 2 & 1 \\
\hline 2. Construct simple sentences & 4 & 3 & 2 & 1 \\
\hline 3. Develop higher-order thinking skills & 4 & 3 & 2 & 1 \\
\hline 4. Develop visual skills & 4 & 3 & 2 & 1 \\
\hline 5. Developing students motivation to learn a new idea & 4 & 3 & 2 & 1 \\
\hline 6. Develop the sense of willingness to accomplish the activity & 4 & 3 & 2 & 1 \\
\hline 7. Enhances grammar skills & 4 & 3 & 2 & 1 \\
\hline 8. Practicing sentence order & 4 & 3 & 2 & 1 \\
\hline 9. Enhance spelling ability while in the game & 4 & 3 & 2 & 1 \\
\hline 10. Provides immediate outcome & 4 & 3 & 2 & 1 \\
\hline 11. It relates the past to new learning experiences & 4 & 3 & 2 & 1 \\
\hline 12. The activity connects with the real world & 4 & 3 & 2 & 1 \\
\hline 13. Encourage active participation & 4 & 3 & 2 & 1 \\
\hline 14. Learning the procedure quickly in doing the activity & 4 & 3 & 2 & 1 \\
\hline 15.It discourages boredom in doing the activity & 4 & 3 & 2 & 1 \\
\hline Most beneficial & 3-Less beneficial - Beneficial & 1-Not beneficial
\end{tabular}

Legend: 4- Most beneficial 3-Less beneficial 2- Beneficial 1-Not beneficial 


\section{Part III. Comfort and Enjoyment experienced in playing GrammarBubbles, Compare, and Falling Clouds}

Encircle four (4) if it provides a lot of fun; three (3) fair in comfort and fun; two (2) a little comfortable,and one(1) if not comfortable in the game.

$\mid$\begin{tabular}{|l|l|l|l|l|}
\hline \begin{tabular}{l} 
1. How much do you enjoy using the computer games? \\
\hline $\begin{array}{l}\text { 2. What is the degree of comfort you feel using } \\
\text { computergames? }\end{array}$
\end{tabular} & 4 & 3 & 2 & 1 \\
\hline $\begin{array}{l}\text { 3. How much experience have you had playing } \\
\text { computergames as a student? }\end{array}$ & 4 & 3 & 2 & 1 \\
\hline $\begin{array}{l}\text { 4. What is the level of difficulty you encounter upon learning } \\
\text { a new word in the game? }\end{array}$ & 4 & 3 & 2 & 1 \\
\hline $\begin{array}{l}\text { 5. Are the games increases your interest in learning English? } \\
\text { 4-A lot A-Fair little }\end{array}$ & 3 & 2 & 1 \\
\hline
\end{tabular}
Legend:

\section{Interview Guide Questions}

1. What were the positive aspects of playing the computer games?

Enjoyable

$\square$ Full of learning

$\square$ Interactive participation

$\square$ Others

Please specify:

2. What were the negative aspects of playing computer games?

Difficult to handle

Discouraging

Time-consuming

Others

Please specify:

3. Computer games enhance:

$\square$ Grammar Skills

$\square$ Vocabulary Skills

$\square$ Comprehension Skills

\section{Inputs in the Computer games:}

* Recall and list ten words in the game Grammar Bubbles, Compare, andFalling Clouds and use it in a sentence? 